\title{
Correspondence
}

\section{Corneal vascularization}

\section{To the Editorial Committee of the British Journal of Ophthalmology}

Sirs,-In an article entitled "Corneal vascularization induced experimentally with corneal extracts" (Brit. F. Ophthal., 1969, 53, 827), P. J. Folca, in a well-designed experiment, suggests that there is no relationship between the degree of corneal swelling and concomitantly produced experimental corneal vascularization. The author concludes that after disorganization of corneal tissue, the release of a vessel-stimulating factor results in corneal neovascularization and that the neovascularization does not appear to be mediated by the production of corneal swelling.

I should like to call Mr. Folca's attention to two articles. In the first, "Congenital hereditary corneal dystrophy" (Amer. F. Ophthal., 1960, 50, 1114 ), A. E. Maumenee points out the association of limbal corneal oedema in combination with the absence of stromal vascularization and suggests that the mere presence of oedema in the periphery of the cornea is insufficient to stimulate neovascularization. In the second, "Corneal edema and corneal vascularization" (Amer. 7. Ophthal., I $968,65,882$ ), J. L. Baum and E. Martola describe a series of patients with Fuchs's dystrophy in whom there was no corneal vascularization and whose mean limbal corneal thickness was $0.919 \pm$ $0.026 \mathrm{~mm}$. (S.E.M.). The paper also presents a second series of patients with actively vascularized corneae, whose mean limbal corneal thickness was $0.849 \pm 0.026 \mathrm{~mm}$. (S.E.M.). The results of the study indicate that a small number of patients are to be found with long-standing limbal oedema and no evidence of vascularization in the oedematous area immediately adjacent to the limbal blood vessels. When adjusted for age group, the limbal corneal thickness in those patients with bullous keratopathy without vascularization was on average approximately 47 per cent. greater than normal, while in the group with active limbal vascularization, the limbal corneal thickness was on average approximately 27 per cent. greater than normal. The authors suggest that corneal oedema is a necessary but not a sufficient stimulus for neovascularization.

In summary, Folca has suggested, on the basis of his experimental results, that corneal oedema is an insufficient stimulus for corneal neovascularization. He has, however, neglected to document the work of previous authors who reached a similar conclusion based on their own data and experimental evidence.

I am in sympathy with the present-day author who must search through a voluminous literature for pertinent articles before presenting his own data. Fortunately, the author is aided in many cases by the reviewer of the journal to which he has submitted his article for publication.

TUFTS UNIVERSITY SGHOOL OF MEDICINE, NEW ENGLAND MEDICAL GENTER HOSPITALS, I 7 I HARRISON AVENUE, BOSTON, MASS., 02 I I I, U.S.A. March 26, 1970
Sincerely yours, Jules L. Baum

\section{Book review}

The Cornea. Macromolecular Organization of a Connective Tissue [Papers from a Symposium held in Kyoto, Japan, 1967.] Edited by M. E. Langham. I969. Pp. 239, figs, refs. Johns Hopkins Press, Baltimore and London. (86s.)

Dr. Johnson remarked (amongst other things) about Lord Chesterfield's patronage that "had it been early, it had been kind". The present volume contains papers presented at a Symposium at 